\title{
The Effect Of Running Dictation Technique Towards Students' Reading Comprehension At The Secondgrade Students Of SMPN 4 Batukliang Utarain Academic Year 2017/2018
}

\author{
Ni Made Pegy Natasia Putri ${ }^{1}$, Muhammad Muhlisin ${ }^{2}$ \\ ${ }^{12}$ Mataram institute of teacher's training and education \\ Faculty of language and art English department \\ FPBS IKIP Mataram \\ muhlisin.fpbs.basma@gmail.com
}

\begin{abstract}
This research is aimed at finding out whether or not Running Dictation technique effective towards students' reading comprehension at the second grade students of SMPN 4 Batukliang Utara in academic year 2018/2019. The research was quasi experimental design with non-equivalent control group design. The instrument used was multiple choice test (narrative text) which consisted of 25 questions and to collect the data used for pre-test and post-test. The population of the study was the second grade students of SMP Negeri 4 Batukliang Utara, which consisted of two classes with the total number of the students were 40 students. The researcher taken the sample by using total population sampling technique.The data was analysis using statistical formula of t-test. The statistical of the data gathered has been already counted. In this term, the result of the value, it is needed consult t-table by using $N-1$ as the degree freedom (df). The $d f$ is $N-1=20-1=19$, having known the value of $\boldsymbol{d} f$, the researcher needed to cheeked up the t-table of $\boldsymbol{d} f 19$. Theresearcher found that the value t-table was 2.093 for confidence level of 0.05 (95\%) and the value t-test was 2.168. $t$ test was higher than t-table $(2.168>2.093)$. In which t-test value was significant. Therefore, it can be concluded that Running Dictation technique is effective towards students' reading comprehension at the second grade students of SMPN 4 Batukliang Utara in academic year 2018/2019.
\end{abstract}

Key Words: Running Dictation Technique, Reading Comprehension

\begin{abstract}
Abstrak. Penelitian ini bertujuan untuk mengetahui apakah teknik Dikte Berlari efektif atau tidak terhadap pemahaman membaca siswa pada siswa kelas dua SMPN 4 Batukliang Utara pada tahun akademik 2018/2019. Penelitian ini adalah penelitian eksperimental semu dengan desain kelompok kontrol tidak setara. Instrument yang digunakan adalah tes pilihan ganda (teks naratif) yang terdiri dari 25 soal dan untuk mengumpulkan data menggunakan pre-test dan post-test. Populasi penelitian adalah siswa kelas dua SMPN 4 Batukliang Utara yang terdiri dari dua kelas dengan jumlah siswa sebanyak 40 siswa. Peneliti mengambil sampel dengan menggunakan teknik total populasi sampling. Analisis data menggunakan rumus statistik uji-t. Data statistik yang dikumpulkan sudah dihitung. Dalam istilah ini, dari hasil nilai, maka perlu berkonsultasi t-tabel dengan menggunakan N1 sebagai derajat kebebasan (df). Df adalah N-1 =20-1=19, setelah mengetahui nilai df, peneliti perlu memeriksa t-tabel dari df19. Peneliti menemukan bahwa nilai t-tabel adalah 2.093 untuk tingkat kepercayaan $0.05(95 \%)$ dan nilai t-test adalah 2.168. t-test lebih tinggi dari t-tabel $(2.168>2.093)$. Dimana nilai uji signifikan. Oleh karena itu, dapat disimpulkan bahwa Teknik Dikte Berlari efektif terhadap pemahaman membaca siswa pada siswa kelas dua SMPN 4 Batukliang Utara pada tahun akademik 2018/2019.
\end{abstract}

Kata Kunci:Teknik DikteBerlari, Pemahaman Membaca

\section{INTRODUCTION}

Reading is a process to getinformation or messages from the text, books, or other writing media. Reading is very important skill for many students taking English language, because the students should read the text to know meaning of the text in their process of learning. According to Moreillon (2007: 10), reading is 
an active process that requires a great deal of practice and skill. It is a complex task. In order to be good readers, learners must sharpen their ability to pronounce words and to "read" pictures and then make the words. Thus, Reading is a process by understanding the text through a media in the form of books, magazines, and so forth to be able to find information submitted by the author in the form of words.

Reading comprehension is the ability to read text, process it and understand its meaning. The ability of individuals to understand the text is influenced by their skills and their ability to process information. Can be seen, there are stillstudents who are lacking in understanding a reading. It can occurdue to lack of students' motivation in learning, student lack of interest in reading, students get bored quickly in reading especially reading English, and so on. So that, the researcher will try to use interesting and different teaching techniques from the teaching technique applied by the teacher that is using Running Dictation technique

Based on the researcher experiencewhen doingTeachingPractice (PPL) atSMPNegeri 4 Batukliang Utara it found that the low students' reading comprehension. Low students' reading comprehension arise for several reasons, as follows; lack of students' ability in determining of the main idea in English text, the students have difficulty understanding in English text because of their low vocabulary, students difficulties of determine detailed information or specific facts of a text, students difficulties in determining exception answers in the text, students difficulties in making a conclusion of the paragraph/story text, students find it difficult to found answers that refer to a word because of the lack students vocabulary, and so on.

Based on the explanation above, the researcher was interested to find out the effect of Running Dictation technique towards students' reading comprehension. This study would be conducted for the eighth grade students of SMPN 4 Batukliang Utara in the academic year 2017/2018.

\section{REVIEW OF RELATED LITERATURE}

\section{Reading}

a. Definition of Reading Comprehension

According to Grellet (1999: 7) reading is a constant process of guessing, and what one finds in it. Based on Johnson (2008: 3) Reading is a complex interaction between the text and the reader which is shaped by the reader's prior knowledge, experiences, attitude, and language community which is culturally and socially situated.

Smith and Dale (1980: 7) state that reading comprehension means understanding, evaluating, utilizing of information and gaining through an interaction between reader and author. Reading comprehension is such a kind of dialogue between reader and author in which the written language becomes the medium that cause the dialogue happen when the two persons communicate through the medium of print reading comprehension refers to reading with comprehension.

Reading is abilitythat a teacher expects the students to acquire at very beginning of the age (Demmrich, 2005: 10). In the early age readers taught to recognize letter, word, morphemes, clauses and sentence. The process of recognizing the syntax and grammatical structure of language is known as bottom up. In this stage readers try to identify the data or the text that will be processed in human brain as stated in (Kintch, 2007: 48) we can regard as a fundamental property of man's intelligence his ability to use cognitive operations for processing not only information obtained from the environment, but also information stored in memory.

Based on the explanation above the writer can conclude that reading is a complex process of interaction between text and readers that can be shaped by knowledge and can obtain information through interaction between readers and writers. Reading is a highly desirable ability by teachers who can be mastered at an early age. In reading, the reader must be able to clearly understand the type of reading they do because it will be easy to achieve their goals in reading.

\section{b. Micro and Macro Skill of Reading}


According to Brown (2003: 187-188) there are micro and macro reading skills.

a. Micro skill for Reading Comprehension:

1. Discriminate among the distinctive graphemes and orthographic patterns of English.

2. Retain chunks of language of different lengths in short-term memory.

3. Process writing at an efficient rate of speed to suit the purpose.

4. Recognize a core of word, and interpret word order patterns and their significance.

5. Recognize grammatical word classes (noun, verb, etc.), systems (e.g., tense, agreement, pluralization) patterns, rules, and elliptical form.

6. Recognize that a particular meeting may be expressed in different grammatical forms.

7. Recognize cohesive devises in written discourse and their role in signaling the relationship between and among clauses.

b. Macro skill for Reading Comprehension

1. Recognize the rhetorical form of written discourse and their significant for interpretation.

2. Recognize the communicative function of writing text, according form and purpose.

3. Infer context that is not explicit by using background knowledge.

4. Form described events, ideas, etc., infer links and connection between events, deduce causes and effects, and detect such relations as main idea, supporting idea, new information, given information, generalization and exemplification.

5. Distinguish between literal and implied meanings. Detect culturally specific references and interpret them in a context of the appropriate cultural schemata.

\section{c. Indicators of Reading}

According to Chesla (2002) there are nine indicators of reading those will be explained as follow:

1. Main idea.
The most important component in written text is main idea or general statement. Writer often put the main idea in the beginning, middle, and in the end of the text. Main idea gathered all of the ideas in paragraph. Here, reader is required to be able to find the main idea.

2. Vocabulary.

Vocabulary refers to lexical items appear in the text. In reading test, test taker often asked to determine the meaning of a word.

3. Specific fact or detail.

Specific fact or detail information refers to the reader ability of finding the detail information given in the text. The detailinformation is the supporting idea which provides author's evidence of the main idea.

4. Exceptions.

Exception refers to question about what is not mention in the text. This question aims to test the reader whether they really understand the text or not.

5. Location of information.

Author often organize their idea or specific information in different way in a paragraph. Here the reader has to locate the specific information given by the author such as Chronological order (time), order of importance, comparison and contrast, cause and effect.

6. Inferences.

It is important for readers to make their own perception of the text they read. Author rarely write the explicit information in the main idea or the general statement therefore the reader ought to have good ability in inferring text.

7. References.

Author often use specific vocabulary as reference for particular sentence means. Reference often causes confusion for reader while refer a word to specific term.

8. Paraphrased sentences (computer-based test only).

First readers read the paragraph and think about what it means while reading. Then readers ask themselves to identify the 
main idea of the paragraph. Finally readers put the main idea and supporting details into their own words.

9. Sentence insertion (computer-based test only).

In this stage readers allowed to put a sentence in paragraph and make it into well-organized paragraph.

\section{d. Stage in Reading}

Harris \& Graham (2007: 103) claimed there are three stages of reading those are explain below:

1. Before reading

Before reading a selection aloud or before reader read a text, they try to build word recognition and background knowledge for a while. It will increase whole comprehension of the text. Readers start this early stage by reviewing the selection and identifying the main concepts of the text. This stage gives readers information about the topic before they read the whole text.

2. During reading

While reading activity, readers read the whole text to find information which exists in the text. It is very important process of reading; in this case the readers use certain strategy to understand the text. Readers try to connect different idea in each passage to gain good understanding of the text.

3. After reading

The main purpose of the Afterreading phase is to check for accurate comprehension of the text. This activity can help readers derive meaning from what they have read and address any misunderstanding which readers may have encountered.

\section{e. Assessment of Reading}

There were some different ways in assessing reading according to Brown (2003: 201), those listed below:

a. Reading aloud. Teacher can assess students by seeing how they separate word, phrases and sentence in reading passage.

b. Written response. The way how the students respond the text they read in written form can help educator to assess students reading comprehension. Teacher difficulty in this kind of assessment is deciding what type of any error occurs in the written response that can be the consequence of the transfer across different skill, reading or writing.

c. Multiple choices. Teacher organizes some test items that provide some answers in which only one of the answer is correct. The use of gambling or guessing in multiple choices can be the interference of the assessment.

d. Picture cued item. Teacher uses picture in assessing students' comprehension. For example, teacher provides a picture in the test and request student to point to the word they read in the test items.

Based on the explanation above, the writer used multiple choices to design assessment for students' reading ability. In this case the used of rubric scoring is very helpful for educator in designing assessment.

\section{Running Dictation Technique}

Ausgabe (2014: 37) defines that "Running Dictation is a technique where the learners run to a text and read it and then pass the information verbally to a partner who either has to write down the entire text or fill in missing words into a gapped text". Furthermore, Newton (2009: 62) defines that "Running Dictation is a kind of dictation where a short dictation text typed in a large font is posted on the wall outside the classroom".

Running Dictation is an amazing technique which involves all of English skill from listening, speaking, reading, and writing. According to Alex (2013: 1) that "Running Dictation is a fun reading, listening and writing task that first learnt about from classic book Dictation: New Methods, New Possibilities by Paul Davies and Mario Rinvolueri".

Based on the explanation above the researcher could concluded that Running Dictation was a technique used by forming students in a group where students follow the text by reading it and passing it on to the partner of groups in charge of the writer. Running Dictation was a fun technique to learn English because students could learn in groups, run, tell and write what they have read.

The Advantages of Running Dictation Technique 
Amy Lightfoot, (2013) cities that advantage of Running Dictation, as follows; (a) Positive Interdependence, (b) It can be a very motivating and fun lesson for the students, (c) Dictation can also be used to promote the skill of inferring from context, (d) Running Dictation has made reading task more fun and interesting, (e) Equal participation each students within the group has an equal opportunity to share.

\section{The Function of Running Dictation}

Nation and Newton (2013: 121) cite that the function of Running Dictation as follows; (a) To make a student read a text in detail, (b) Can be taken from material that the learners have studied before or will study, (c) Help the students learn by managing the time, being disciplined, cooperative and responsible, (d) it also makes students more active in learning process, (e) Improves the student's ability to learn with a group not individual, (f) Easier to apply in the classroom, (g) Makes students feel free to read English without intimidation, (h) Can reduce stress and boredom to accomplish reading task in the classroom, (i) Can help students to improve and practice their reading, listening, speaking, writing, and their critical thinking skill.

\section{The Purpose of Running Dictation}

Amy Lightfoot, (2013) said, in Running Dictation, there are purposes of Running Dictation as follows; (a) Students are able to process information, (b) Students become actively involved in thinking about the concepts presented in the lesson, (c) This activity is often used to inject some fun into the learning, or to enliven a tired class, (d) It can also be useful for introducing a new theme or topic, (e) Students can focus on both accuracy (form) as well as meaning, (f) Students can develop all four skills - speaking and pronunciation can be developed if the students do the dictating rather than the teacher, (g) Give students the opportunity to notice features of pronunciation such as weak forms, linking and elision.

\section{The Procedure of Running Dictation Technique}

Davis and Rinvolucri (1998) in Wright's book entitled Games for Language
Learning third edition, explain the procedure of Running Dictation strategy as follow; 1. The teacher put the texts on the wall. The teacher can put one or more text, 2 . The teacher divides the students into two or more groups. Then, the members of the group decide the students who will be the runner of the writer, 3. Explain the rules of the game. The teacher explains the rule of the Running Dictation to the students. Here are the example of the rule; (a) First runner must run to the text, read it, and try to memorize as much as possible before running back to the writer, (b) First runner should then dictate what they remember of the text to writer, who should record it in writing, (c) The first runner can run to the text as often as is necessary to complete dictating the whole text, (d) Applaud the first pair or group to finish with no mistakes. Then teacher can continue to another pair or group (2006: 90).

\section{RESEARCH METHOD Research Design}

Research design is the preparation of the design of the research project (Kothari, 2004: 31). The research design would used in this study was an experimental design in the form of quasi experimental with non-equivalent control group design. The researcher would take two groups for experimental group and control group. The researcher gives different treatments for two groups. This study was aimed at finding out the effect of Running Dictation technique towards students' reading comprehension to second grade students at Junior High School.

\section{Population of the Study}

So population is set of some object/subject the researcher take the object/subject as the researching. Arikunto (2002: 31), stated population research can be done for limited population and the subject is not too much. In the research population which consists of two classes VIII/A (20 Students) and VIII/B (20 Students) therefore, all of them were 40 students. In this case, the researcher takes the sample by using total population sampling technique. 


\section{Instrument of the Study}

Sugiyono, (2014: 148), states that research instrument was the tool that is used to measure the nature or social phenomena being researched. This research used multiple choices that consist of 25 questions to measure the students' reading comprehension. In which multiple choice test consist of option ( $\mathrm{a}, \mathrm{b}, \mathrm{c}$, or d) each correct answer used get score 1 and wrong answer used get score 0 , so the maximum score was 100 .

\section{Techniques of Data Collection}

The researcher used test to collect data. The test was in the form of multiple choices. The students were tested by reading comprehension test. The test given before and after the researcher taught the students by using Running Dictation technique to the experimental class and using Jigsaw technique to the control class. There were two kinds of test that would be given by the researcher that were pre-test and post-test.

\section{Technique of Data Analysis}

1. Descriptive Analysis

$$
\begin{aligned}
& \text { a. Mean } \\
& \mathrm{X}_{1}=\frac{\sum \mathrm{X}_{1}}{N_{1}} \\
& \text { Miller (2005: 67) }
\end{aligned}
$$

\section{b. Median}

$\operatorname{Mdn}=\mathrm{L}+\left(\frac{\frac{1}{2} \mathrm{~N}-\mathbf{f k}_{\mathbf{b}}}{\mathbf{f}_{\mathbf{i}}}\right)$

Anas Sudijono (2007: 97)

$$
\begin{aligned}
& \text { c. Mode } \\
& M_{O}=L+\left(\frac{f_{a}}{\mathbf{f}_{\mathbf{a}}+\mathbf{f}_{\mathbf{b}}}\right)
\end{aligned}
$$

Anas Sudijono (2007: 106)

\section{d. Standard Deviation}

$$
\mathrm{SD}=\sqrt{\frac{\sum D^{2}}{N}-}\left(\frac{\sum D}{N}\right)^{2}
$$

AnasSudijono (2007: 306)

2. Normality and Homogenity Data

a. Formula of normality data

$$
\frac{(f o-f h)^{2}}{f h}
$$

(Sugiyono, 2016: 82)

b. Formula of homogeneity data

$$
\mathrm{F}=\frac{\text { the biggest variant }}{\text { the smallest variant }}
$$

(Sugiyono, 2016: 175)

3. Inferential Analysis

$$
\begin{aligned}
& \text { Testing Hypothesis (t-test) } \\
& t=\frac{\boldsymbol{M}_{\mathbf{1}}-\boldsymbol{M}_{\mathbf{2}}}{\sqrt{\left(\frac{\sum \boldsymbol{X}_{1}^{2}+\sum \boldsymbol{Y}_{2}^{2}}{\mathbf{N}_{1}+\mathbf{N}_{2}-\mathbf{2}}\right)}\left(\frac{\mathbf{N}_{1}+\mathbf{N}_{2}}{\mathbf{N}_{1} \cdot \mathbf{N}_{2}}\right)}
\end{aligned}
$$

(Anas Sudijono, 2007: 318)

\section{RESEARCH FINDING AND DISCUSSION}

The researcher presented the result of the study. The score of Experimental Group and Control Group pre-test and post-test were taken from the data of the study. Therefore, the researcher presented a discussion in order to answer the statement of the problem in the previous chapter (Chapter 1), "Is Running Dictation technique effective towards students' reading comprehension at the second grade students of SMPN 4 Batukliang Utara in academic year 2017/2018?'. To found out the solution of the problem on the research intends to analyze the data obtained from students' test result. Data of the study consists of two steps, pre-test and post-test. The first step was pretest, it conducted to know the students' ability before giving the treatment, then the second steps was post-test as the last of the test. The researcher gave a multiple choice test consists of 25 items of multiple choice as a pre-test and post-test to know students' ability in reading comprehension. The discussion continued to analyzing and interpreting the finding. The statistical compulation covered the calculation of pre-test, posttest, deviation, and deviation square.

The data collected that was taking from in experimental group 20students and control group 20 students. The total score of pre-test in experimental group is 1420, the score of pre-test experimental group showed the highest score is 84 and the lowest score is 60 with the average 71 , meanwhile the total score of post-test in experimental group is 1614 , the score of post -test experimental group showed the highest score is 88 and the lowest score is 72 with the average 80.70 . The result of data analysis showed that the total score of Pretest

is $\sum 1420$, Posttestis $\sum 1614$ Deviationis194, and Deviation Square is 3108.The standard deviation of pre- 
test and post-testexperimentalgroup is $\mathrm{SD}_{\mathrm{D}}=7.830$. The score of experimental group between pre-test and post-test isdifferent. It is can summarized that the lowest and the highest score in post-test is higher than in the pre-test. Itchanged after the give treatment taught using Running Dictation technique

The total score of pre-test in control group is 1408, the score of pre-test control group showed the highest score is 80 and the lowest score is 60 with the average 70.40, meanwhile the total score of post-test in control group is 1468, the score of post -test control group showed the highest score is 84 and the lowest score is 64 with the average 73.40

From the analysis of the data above, it is find that t-test value is 2.168 and t-table is 2.093 for confidence level $0.05(95 \%)$. It is mean that the t-test is higher than t-table.

\section{Discussion}

The statistical of the data gathered has been already counted. In this term, the result of the value, it was needed consult t-table by using $\mathrm{N}-1$ as the degree freedom $(\mathbf{d f})$. The df is $\mathrm{N}-1=$ $20-1=19$, having known the value of $\mathbf{d f}$, the researcher needed to cheeked up the t-table of df19. And the researcher found that the value was 2.093 for confidence level of 0.05 (95\%). This was taken based on the result on the t-test, it was found that t-test was 2.168 and t-table at significance level of 0.05 (95\%) was 2.093 with 40 samples. Thus, t-test was higher than t-table.

Newton (2009: 62) defines that "Running Dictation is a kind of dictation where a short dictation text typed in a large font is posted on the wall outside the classroom.Running Dictation technique has effect towards students' reading comprehension. The data analysis of Post-test showed score of Experimental Group was higher than the Control Group (80.70 $\geq 73.40)$. In this case, there was significant different of the both group. The Experimental Group was taught by Running Dictation technique and Control Group was taught by using Jigsaw technique. It means that Running Dictation technique as teaching method in Experimental Group was better than Jigsaw technique as teaching method in Control Group.
Based on the condition above, the researcher concluded that alternative hypothesis $\left(\mathrm{H}_{\mathrm{a}}\right)$ which stated "Running Dictation technique is effective towards students' reading comprehension at the second grade students of SMPN 4 Batukliang Utara in academic year 2018/2019, clearly was accepted

\section{CONCLUSION AND SUGGESTION Conclusion}

Running Dictation technique has positive effect towards students' reading comprehension at the second grade students of SMPN 4 Batukliang Utara in academic years 2018/2019. The next step the researcher needs to make conclusion. It is purposed that researcher makes the research can be understood easily about this study which is students' reading comprehension using Running Dictation technique can be effective. Therefore, there are some main points of research that must be concluded, such as: (1) The result of mean score in experimental group is 80.70 and the result ofmean score in control group is 73.40, (2) Using Running Dictation technique is more effective than not using Running Dictation technique, its shows that Alternative Hypothesis (Ha) is accepted. This was taken based on the result of the t-test, it was found that t-test was 2.168 and t-table at significance level of 0.05 was 2.093 . thus, t-test was higher than t-table. So, it indicated that "Running Dictation technique" can be used in teaching Reading Comprehension.

Finally, the analysis and the interpretation of data eventually lead the researcher to the conclusion that Running Dictationhas positive effect towards students' reading comprehension at the second grade students of SMPN 4 Batukliang Utara in academic years 2018/2019. It can be provided by the result of post-test in experimental group is higher than the control group.

\section{Suggestion}

Based on the conclusion above, the researcher would like to offer some suggestion as follows: (1) For the English Teachers. The researcher hopes that teachers can create various methods or ways to teach English. The researcher hope the teacher can re-implement of 
Running Dictation technique to teach reading comprehension, so that it becomes more effective and interesting, (2) For the Students. The researcher hope students to be more interested in learning English. The students must reduce laziness in reading and try to learn English in a fun way using Running Dictation technique, (3) For the Next Researchers. This research as a new experience to the researcher and also about the use of a good method to increase the result of students study in teaching and learning process, especially in reading by using this method.

\section{BIBLIOGRAPHY}

(I.S.P. Nation and J. Newton.Teaching ESL/EFL Listening and Speaking. (New York: Rutledge, 2009)).

Aini, ArinAldila. 2015. "The Use of Running Dictation Technique to Improve Students' Writing in Descriptive Text (An Action Research of the Tenth Graders of SMAN 1 BawangBanjarnegara in the Academic Year 2014-2015).

Arikunto, Suharsimi. 1998.

ProsedurePenelitianSuatuPendekatan Praktek. Rineka.Cipta: Jakarta.

Brown, H Douglas. 2001. Teaching by Principles. Addison Wesley Longman, Inc.

Fulcher, G., \& Davidson, F. 2007. Language testing and Assessment: an advanced resource book. New York: Rotledge.

Harmer, J. 2001.How to teach English.An Introduction to the Practice of English Language Teaching. Longman

Huges, A. 2003.Testing for Language Teachers Second Edition., P.78

Kothari, C.R. 2004. Research Methodology, Methods and Technique Second Edition.Jaiput: New Age International.

Miller, Steve. 2005. Experimental Design and Statistics. France: International Thomson Publishing Company.

Sudijono, Anas. 2007. PengantarStatistikPendidikan. PT RajaGrafindoPersada. Jakarta.
Sugiyono. 2012. MetodePenelitianKuantitatif, Kualitatif, dan $\mathrm{R}$ \& D. Bandung: Alphabet acv.

Sugiyono. 2014.

MetodePenelitianKuantitatifKualitatif dan R\&D. Bandung: Alphabeta

Sugiyono. 2014. StatistikaUntukPenelitian. Bandung: Alphabeta

Widayanto. 2005. "The Effect of Using Running Dictation strategy to Improve Listening Skill of the Third Year Students at MAN 3 Malang".

Wright, Andrew.,Betteridge, David., and Bockby, Michael. 2006. Games for Language Learning Third Edition. (Cambridge Handbook for Language Teachers).Miller, Steve. 2005. Experimental Design and Statistics. France: International Thomson Publishing Company. 